\title{
Seasonal variation in the essential oil of Pilocarpus microphyllus Stapf.
}

\author{
FRANCISCA S. N. TAVEIRA ${ }^{1}$, ELOISA H. A. ANDRADE ${ }^{2}$, WATERLOO N. LIMA $^{3}$ \\ and JOSÉ G. S. MAIA ${ }^{3}$ \\ ${ }^{1}$ Universidade Federal do Maranhão, Departamento de Química, 65080-040 São Luis, MA, Brazil \\ ${ }^{2}$ Museu Paraense Emílio Goeldi, Departamento de Botânica, 66040-170 Belém, PA, Brazil \\ ${ }^{3}$ Universidade Federal do Pará, Departamento de Química, 66075-900 Belém, PA, Brazil
}

Manuscript received on June 27, 2002; accepted for publication on November 22, 2002;

presented by Fernando Galembeck

\begin{abstract}
The essential oils of the leaves and fine stems of Pilocarpus microphyllus, collected on iron mineralized soil of the Serra de Carajás, Southeast of Pará State, Brazil, during the rainy and dry seasons, were obtained by hydrodistillation and analyzed by GC-MS. The main identified compounds were 2-tridecanone, $\beta$-caryophyllene, 2-pentadecanone, caryophyllene oxide and germacrene $\mathrm{D}$. Their percentage contents varied with the season, the greater values having been detected mainly in the rainy season. For 2-tridecanone and $\beta$-caryophyllene the higher values were observed in the fine stem oils for the former, and in the leaf oils for the latter. For 2-pentadecanone, caryophyllene oxide and germacrene D they were also in the leaf oils. In general, the leaf oils were very distinguishable from those of fine stem oils, even in the same specimen.
\end{abstract}

Key words: Pilocarpus microphyllus, Rutaceae, jaborandi, essential oil composition, 2-tridecanone, 2pentadecanone, sesquiterpenes.

\section{INTRODUCTION}

The genus Pilocarpus (Family Rutaceae) comprises about 13 species, 7 subspecies and 8 varieties occurring throughout the neotropics, but completely absent from the Amazon Basin (Kaastra 1982). Most of them are distributed from the South of Pará State to Northeast Brazil where they are used as medicinals. The species Pilocarpus microphyllus Stapf. is known as "jaborandi" or " jaborandi-do-maranhão" in the East Amazon and its leaves are used as diuretic, sudorific, digestive, sialogogue, hair tonic, for eye inflammation, and mainly for industrial extraction of pilocarpine, an imidazole alkaloid with

Correspondence to: José Guilherme Maia

E-mail: gmaia@museu-goeldi.br cholinergic activiy (Sousa et al. 1991, Pio Corrêa 1984, Maia et al. 2001).

The oils of the species of $P$. racemosus (Guadeloupe jaborandi), P. microphyllus (Maranham jaborandi) and $P$. spicatus (Aracati jaborandi) were previously reported as containing an appreciable content of 2-nonanone (Guenter 1972). Later on these data were reviewed after the analysis of the steam distilled oils from $P$. jaborandi (Pernambuco jaborandi), P. microphyllus and P. pauciflorus (subspecies of P. spicatus) (Craveiro et al. 1979, 1981). According to this study the main compounds found in the oil of $P$. jaborandi were limonene and 2-undecanone; in the oil of $P$. microphyllus were caryophyllene and 2-tridecanone; and in the oil of $P$. 
pauciflorus were sabinene and 2-undecanone. The essential oils of some plant parts of two specimens of $P$. trachyllophus (Ceará jaborandi) was also analyzed and the major identified constituents were $\beta$-caryophyllene, germacrene $\mathrm{D}, 2$-tridecanone, spathulenol and 2-pentadecanone (Andrade-Neto et al. 1995, 2000).

Now, we wish to report the chemical composition of the essential oils of three specimens of $P$. microphyllus growing wild in the Mineral Province of the Serra de Carajás, Southeast of Pará State, Brazil, in an iron mineralized soil, during the rainy and dry seasons. The work was part of a project to identify biogeochemical markers of mineral soils in the Amazon, based on essential oil analysis (Taveira 1991).

\section{MATERIALS AND METHODS}

\section{MATERIAL AND EXTRACTION OF}

VOLATILE CONSTITUENTS

The leaves $(F)$ and fine stems $(\mathrm{G})$ of four specimens of $P$. microphyllus were collected in the $\mathrm{N}-1$ area (iron mine) belonging to Companhia Vale do Rio Doce (CVRD), in the Serra de Carajás, Southeast of Pará State, Brazil, during the rainy (March/April) and dry (October/November) season. Voucher specimens (\#131.456) have been kept at the herbarium of Museu Paraense Emílio Goeldi, in the city of Belém, Pará State, Brazil. The plant parts of samples 131F, 131G, 180F, 180G, 199F and 199G were air-dried for 48 hours, mill powdered to furnish 200 $\mathrm{g}$ each, and separately hydrodistilled for $4 \mathrm{~h}$ using a Clevenger-type apparatus. The aerial part (leaves and fine stems) of PPCE138 sample was air-dried for 5 days, mill powdered (200g) and submitted to hidrodestillation at the same condition. The distilled oils were dried over anhydrous sodium sulfate and the percentage contents were calculated on basis of the dry weight of plant material. The plant collection site and the oil yields are listed in Table I.

\section{ANALYSIS OF THE VOLATILE CONSTITUENTS}

Analyses of the volatile compounds were performed on two GC/MS instruments: a (1) HP 5988 and a (2)
Finnigan Mat INCOS XL, under the following conditions: (1)WCOT SE-54 $(25 \mathrm{~m} \times 0.32 \mathrm{~mm} ; 0.25 \mu \mathrm{m}$ film thickness) and (2) WCOT DB-5ms (30m $\times$ $0.25 \mathrm{~mm} ; 0.25 \mu \mathrm{m}$ film thickness) fused silica capillary columns; temperature programmed: (1) $50^{\circ} \mathrm{C}$ $180^{\circ} \mathrm{C}\left(4^{\circ} \mathrm{C} / \mathrm{min}\right)$ and $180^{\circ} \mathrm{C}-250^{\circ} \mathrm{C}\left(2^{\circ} \mathrm{C} / \mathrm{min}\right)$ and (2) $60^{\circ} \mathrm{C}-240^{\circ} \mathrm{C}\left(3^{\circ} \mathrm{C} / \mathrm{min}\right)$; injector temperature: $220^{\circ} \mathrm{C}$; carrier gas: $\mathrm{He}$, adjusted to a linear velocity of $32 \mathrm{~cm} / \mathrm{sec}$ (measured at $100^{\circ} \mathrm{C}$ ); split flow was adjusted to give a 20:1 ratio; injection type: splitless ( $1 \mu 1$, of a 1:1000 hexane solution); EIMS: electron energy, $70 \mathrm{eV}$; ion source temperature and connection parts: $180^{\circ} \mathrm{C}$.

Individual components were identified by comparison of both mass spectrum and their GC retention data with those of authentic compounds previously analyzed and stored in the data system. Other identifications were made by comparison of mass spectra with those in the data system libraries and cited in the literature (Adams 1995). The retention indices (RI) were calculated for all volatile constituents using an $n$-alkanes homologous series at the same GC conditions.

\section{RESULTS AND DISCUSSION}

Based on GC-MS analysis 27 compounds were identified in the oil samples of $P$. microphyllus. These data are listed in Table II. The main compounds were 2 -tridecanone, $\beta$-caryophyllene, 2-pentadecanone, caryophyllene oxide and germacrene $\mathrm{D}$. Their percentage contents varied with the season, the greater values having been found mainly in the rainy period. The higher contents of 2-tridecanone and $\beta$-caryophyllene were observed in the fine stem oils (131G: $36.0 \%$; 199G: $64.1 \%$ ) for the former, and in the leaf oils (131F: $40.6 \%$; 199F: 29.2\%) for the latter. The higher contents of 2-pentadecanone was in the leaf oil (131F: 28.1\%); and for caryophyllene oxide (199F: $15.4 \%)$ and germacrene D (131F: $10.5 \% ; 199 \mathrm{~F} ; 8.4 \%)$ were in the leaf oils. In general, the leaf oil composition was very distinct from those of the fine stem oils, even for the same specimen, as observed for the samples $180 \mathrm{~F}$ and $180 \mathrm{G}$, 
TABLE I

Collection data and oil yields of the samples of Pilocarpus microphyllus.

\begin{tabular}{c|c|c|c|c|c}
\hline Reg. No. & Plant Part & Season & Collection Site & Vegetation Type & Oil Yield (\%) \\
\hline $131 \mathrm{~F}$ & Leaves & Rainy & N-1 area, iron mine & Canga & 0.4 \\
$131 \mathrm{G}$ & Fine stems & & & & 0.2 \\
\hline $180 \mathrm{~F}$ & Leaves & Dry & N-1 area, iron mine & Canga & 0.3 \\
$180 \mathrm{G}$ & Fine stems & & & & 0.2 \\
\hline $199 \mathrm{~F}$ & Leaves & Rainy & N-1 area, iron mine & Canga & 0.3 \\
$199 \mathrm{G}$ & Fine stems & & & & 0.2 \\
\hline PPCE138 & Leaves and fine stems & Dry & N-1 area, iron mine & Canga & 0.2 \\
\hline
\end{tabular}

Canga - Top soil made up mostly of iron oxides.

collected in the dry season. Analyzing the principal methyl ketones, probably originated from the same biosynthetic pathway, it was observed that the pair 2-tridecanone:2-pentadecanone presented an inversion of their percentage contents, according with the analyzed plant part. For example, the values for 2tridecanone and 2-pentadecanone in the $199 \mathrm{~F}$ leaf oil were $2.4 \%$ and $14.2 \%$, respectively, contrasting with those observed in the $199 \mathrm{G}$ fine stem oil, that were $64.1 \%$ and $18.9 \%$, respectively. The same inversion can be observed for the other samples (131F:131G and 180F:180G). The leaf and fine stem oils obtained from the specimen PPCE138, collected during the dry season, presented the higher percentage content for 2-tridecanone $(88.1 \%)$. This noteworthy value is attributed to a longer sample drying time when other more volatile compounds were probably lost.

In the present study it was not possible to identify the monoterpenes limonene, $\beta$-ocimene and $\alpha$-pinene, as well as the hydrocarbon 3,7,7trimethylbicyclo[3,1,1]-2-heptene, previously described for P. microphyllus oil (Craveiro et al. 1979, 1981). On the other hand, the chemical composition reported for the P. trachyllophus oil (Andrade-Neto et al. 1995, 2000) showed some similarities with our analyses, except for the conspicuous presence of spathulenol, in the place of caryophyllene oxide, found by us in the oil of P. microphyllus.

These results are based on single samples at each collection site and do not take into account the within site variation. However, the chemical composition of the analyzed essential oils showed qualitative and quantitative variation by the influence of local environmental conditions of soil and seasonal period of collections. These findings have ecological and taxonomic significance for the species application as biogeochemical or chemotaxonomic markers.

\section{ACKNOWLEDGMENTS}

The authors are grateful to MCT-PPG7/European Community, MMA-PROBEM and CNPq-PNOPG for financial support.

\section{RESUMO}

Os óleos essenciais das folhas e galhos finos de Pilocarpus microphyllus, coletado em solo mineralizado com ferro, na Serra de Carajás, Sudeste do Pará, Brasil, durante as estações chuvosa e seca, foram obtidos por hidrodestilação e analisados por GC-MS. Os principais compostos identificados foram 2-tridecanona, $\beta$-cariofileno, 2 pentadecanona, óxido de cariofileno e germacreno D. Seus teores percentuais variam com a estação, embora os maiores valores tenham sido detectados principalmente na estação chuvosa. Para 2 -tridecanona e $\beta$-cariofileno os valores mais expressivos foram observados nos óleos de galhos finos, para o primeiro, e nos óleos das folhas, para o útimo. Para 2-pentadecanona, óxido de cariofileno e germacreno 
TABLE II

Volatile constituents (\%) of the essential oils of Pilocarpus microphyllus.

\begin{tabular}{l|c|c|c|c|c|c|c|c|c}
\hline Constituents & RI* & \multicolumn{2}{|c|}{ Rainy season } & \multicolumn{2}{c|}{ Dry season } & \multicolumn{2}{c}{ Rainy season } & Dry season \\
\hline & & Sample & Sample & Sample & Sample & Sample & Sample & Sample \\
& & $131 \mathrm{~F}$ & $131 \mathrm{G}$ & $180 \mathrm{~F}$ & $180 \mathrm{G}$ & $199 \mathrm{~F}$ & $199 \mathrm{G}$ & PPCE138 \\
\hline$\delta$-Elemene & 1336 & - & - & - & 0.8 & - & - & - \\
$\alpha$-Cubebene & 1348 & - & - & 0.3 & 2.0 & - & - & - \\
$\alpha$-Copaene & 1371 & 2.0 & 0.7 & 1.8 & 4.4 & 4.7 & 0.6 & 0.2 \\
$\beta$-bourbonene & 1380 & 0.9 & - & 1.8 & 0.8 & 3.4 & & - \\
$\beta$-Cubebene & 1384 & 1.4 & - & 1.5 & 1.1 & 2.8 & - & - \\
$\beta$-Elemene & 1387 & - & - & - & 1.5 & - & - & - \\
$\alpha$-Gurjunene & 1404 & - & - & - & 1.2 & - & - & - \\
cis- $\alpha$-Bergamotene & 1410 & - & - & - & 0.9 & - & & - \\
$\alpha$-Caryophyllene & 1417 & 40.6 & 7.8 & 23.9 & 8.0 & 29.2 & 7.5 & 2.5 \\
$\beta$-Gurjunene & 1427 & - & - & 0.4 & - & - & - & - \\
trans- $\alpha$-Bergamotene & 1432 & - & - & 0.9 & 4.2 & - & - & - \\
Aromadendrene & 1435 & - & - & - & 0.7 & - & - & - \\
(Z)- $\beta$-Farnesene & 1438 & - & - & 0.3 & - & - & - & - \\
$\alpha$-Humulene & 1447 & 1.7 & 1.1 & 3.2 & 2.5 & 5.4 & 0.9 & 0.1 \\
(E)- $\beta$-Farnesene & 1453 & - & - & 0.8 & 1.4 & - & - & - \\
Germacrene D & 1475 & 10.5 & 3.2 & 6.6 & 7.9 & 8.4 & 2.8 & 0.5 \\
$\beta$-Selinene & 1480 & - & - & - & 1.5 & - & - & - \\
2-Tridecanone & 1489 & 11.1 & 36.0 & 20.4 & 30.1 & 2.4 & 64.1 & 88.1 \\
$\beta$-Bisabolene & 1504 & - & - & 0.8 & 2.4 & - & - & - \\
$\beta$-Sesquiphellandrene & 1520 & 0.5 & 1.1 & 3.4 & 2.6 & 2.4 & 0.6 & - \\
(E)-Nerolidol & 1560 & - & - & 0.4 & 1.2 & - & - & - \\
Spathulenol & 1571 & - & 1.6 & 2.7 & 0.8 & 1.1 & - & 0.1 \\
Caryophyllene oxide & 1577 & 2.7 & 6.9 & 4.4 & 5.6 & 15.4 & 2.8 & 0.3 \\
2-Tetradecanone & 1584 & - & - & - & 1.2 & 1.5 & 0.8 & 0.1 \\
Carotol & 1589 & - & - & 0.6 & 2.2 & - & - & - \\
Humulene epoxide II & 1601 & - & 1.4 & 0.3 & - & 1.7 & - & - \\
Unidentified hydrocarbon & 1645 & 0.5 & 6.9 & 3.1 & - & 0.8 & 0.5 & - \\
2-Pentadecanone & 1650 & 28.1 & 26.4 & 20.8 & 6.7 & 14.2 & 18.9 & 6.9 \\
Unidentified & & & & & & & & \\
$\quad$ sesquiterpenes & & - & 4.1 & - & 6.6 & 5.4 & - & 1.2 \\
\hline$\%$ Total & & 100.0 & 97.2 & 98.4 & 98.3 & 98.8 & 99.5 & 100.0 \\
\hline & & & & & & & & \\
\hline
\end{tabular}

$* \mathrm{RI}=$ Retention Index, on SE-54 and DB-5ms columns.

D, os valores mais altos foram, também, nos óleos das folhas. Em geral, os óleos das folhas se apresentaram muito distintos em relação aos galhos finos, assim como também no mesmo espécime.

Palavras-chave: Pilocarpus microphyllus, Rutaceae, jaborandi, composição do óleo essencial, 2-tridecanona, 2- pentadecanona, sesquiterpenos.

\section{REFERENCES}

ADAMS RP. 1995. Identification of essential oil components by gas chromatography/mass spectroscopy. Allured Publishing Corporation, Illinois, 1995, 469p. 
Andrade-Neto M, Mafezoli J, Cunha UA, Silveira SC AND SILVEIRA ER. 1995. Volatile constituents of Pilocarpus trachyllophus Holmes. J Essent Oil Res 7: 671-674.

Andrade-Neto M, Cunha UA, Mafezoli J and SilVEIRA ER. 2000. Volatile constituents of Pilocarpus trachyllophus Holmes and Pilocarpus jaborandi Holmes (Rutaceae) from Northeast of Brazil. J Essent Oil Res 12: 769-774.

Craveiro AA, Andrade ChS, Matos FJA and AlenCAR JW. 1979. Essential oils from brazilian Rutaceae. 1. Genus Pilocarpus. J Nat Prod 42: 669671.

Craveiro AA, Fernandes AG, Andrade CHS, Matos FJA, AlENCAR JW AND Machado MIL. 1981. Óleos essenciais de plantas do nordeste. Edições UFC, Fortaleza, 1981, 209p.

Guenter R. 1972. The essential oils, Robert E. Krieger Publishing Co., Inc., New York, 1972, vols 1-5.
KaASTRA RC. 1982. Pilocarpinae (Rutaceae). Flora Neotropica, Organization for Flora Neotropica, The New York Botanical Garden, New York, Monograph Number 33: 16-197.

Maia JGS, Zoghbi MGB and Andrade EHA. 2001. Plantas aromáticas na Amazônia e seus óleos essenciais. Museu Paraense Emílio Goeldi, Belém, 173p.

Pio CorrêA M. 1984. Dicionário das plantas úteis do Brasil e das exóticas cultivadas. Instituto Brasileiro de Desenvolvimento Florestal, Rio de Janeiro, 1984, Vols 1-6.

Sousa MP, Matos MEO, Matos FJa, Machado MIL and Craveiro AA. 1991. Constituintes químicos ativos de plantas medicinais brasileiras. Edições UFC, Fortaleza, 1991. 416p.

Taveira FSN. 1991. Plantas aromáticas da Serra de Carajás como prováveis marcadores biogeoquímicos de solos mineralizados. Dissertação de Tese de Mestrado, Programa de Pós-Graduação em Química de Produtos Naturais, Universidade Federal do Pará, Belém, 1991, 97p. 